\title{
PROFITABILITY OF MULTI-NATIONAL CORPORATIONS IN THE CONTEXT OF SUSTAINABLE DEVELOPMENT: SCANIA BUSINESS PRACTICES
}

\author{
V.R. PARTSVANIYA
}

Institute of Social Sciences, Russian Presidential Academy of National Economy and Public Administration, Russia ${ }^{a}$ Scania-Rus, Russia

In this article, I explore the relationship between sustainable development and commercial success by using the example of the multi-national corporation (MNC), Scania. Despite broad discussion of necessity for businesses to be actively engaged in the sustainable development goals at global and national level, only a small number of MNCs are actually taking concrete action towards reaching any of them. In reality, corporations' commitment to these goals often remains of a declaratory nature. Actions by organizations to emphasise social responsibility and environmental obligations have rarely been connected to generating income. This work attempts to investigate sustainable development as a source of new business opportunities to bring MNCs additional income. By looking at concrete business practices from Scania, I illustrate how corporations may adjust their strategic behavior, approaches, and positioning in the global market within the context of the sustainable development paradigm. The analysis is based on the public account records and official documents of Scania, as well as the company's official website and open sources of information.

Keywords: sustainable development, multi-national corporations, Scania, business practices, digital technology, corporate social responsibility.

JEL: F64, M14, Q01, Q42, Q56.

\section{INTRODUCTION}

Over the past decades, the global business community has been paying increasing attention to the concept of sustainable development and corresponding organizational prac- tices. Environmental problems are being exacerbated: wuth fresh food and water shortages, climate change, and the emission of harmful substances into the water, air, soil all increasing, while forest coverage and biodiversity decrease. The global population is growing

Organization addresses: a 82/1, pr. Vernadskogo, Institute of Social Sciences, Russian Presidential Academy

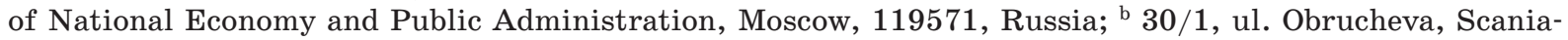
Rus, Moscow, 117485, Russia.

(c) V. R. Partsvaniya, 2020

https://doi.org/10.21638/spbu18.2020.105 
fast: by 2050 it will have reached 9.7 bn people [World Population Prospects, 2019], which will lead to further increases in emissions and ecological pressure. Other critical problems include poverty and inequality, access to high-quality education and healthcare, the development of urban and agricultural territories, the production of clean energy and the supply of energy to remote regions.

International organizations and institutions and government authorities emphasize the need to balance economic, environmental, and social aspects in the system of values of the various actors in contemporary international politics and the global economy. The General Assembly of the UN approved sustainable development goals (SDG) for 20162030, which set the direction for this process and outline a course of action. It included 17 goals divided into 169 tasks, the effectiveness of which are to be evaluated by 230 indicators. This suggests that "consensus is reached in the world on development in the XXI century, connected with the transition to sustainable development" [Bobylev, 2017, p. 91].

Business organisations are to play an important role in achieving the SDGs, especially those by multi-national corporations (MNCs) that possess vast financial and economic resources and operate across the world. However, level of engagement that these businesses have with the goals of sustainable development remains relatively modest. On the one hand, public support for the SDGs is an integral part of the reputation, image, and operational activities of many MNCs [Carroll, Shabana, 2010; Kolk, 2016]. This reflected by the integration of the principles of sustainable development in corporate culture, the introduction of socially-important and environmental initiatives, and organizational projects to reduce energy use and harmful environmental effects, as well as corresponding reporting and disclosure activity. Today, we see clear evidence that business has become more socially responsible, developing ecological, innovative, digital and energy-efficient solutions that cause significantly less harm to the environment while providing benefits to society. However, despite this, few MNCs undertook concrete actions towards any of the SDGs. Business still views investment in this sphere exclusively as a source of financial loss, with the benefits being generally perceived as something vague. Because of this, engagement of many companies in the achievement of the SDGs remains very limited.

Currently only around 200 out of the 729 largest MNCs operating in 21 countries and representing 6 industrial sectors mention the SDGs in any way in their business strategies [Scott, McGill, 2018]. Smaller firms were found to be even less involved in the achievement of the SDGs [Laudal, 2011]. Many large organizations believe that their contribution to the development of society, the economy, and the protection of the environment should be limited to their main business activity [2030 Purpose..., 2017]. Russian practice shows similar tendencies: as is shown by the surveys conducted by the Russian national network for the UN Global Compact, "the majority of companies do not yet connect their strategic goals with the SDGs and do not use them in the development of their performance indicators", and only a few large, leading companies "actively incorporate the key performance indicators of the SDGs in their activities" [Dolgikh, Erlich, 2018, p. 12].

At the same time, businesses often overlook the fact that the sustainable development agenda includes significant potential for the realization of commercial opportunities. This is confirmed by a number of studies published in the last few years [Porter, Kramer, 2019; Eccles, Ioannou, Serafeim, 2014; Blagov et al., 2015]. In particular, it affects new market niches created under the influence of global trends; from the development of alternative energy sources and changes to the global structure of energy use to a transformation of consumer preferences towards the use of ecologically friendly products, recycled materials, and resource conservation. In fact, over the last few decades, these trends have substantially changed the face of traditional 
industries. Industrial corporations producing dangerous and labor- and energy-intensive products have begun to actively incorporate innovations and the latest technology into their production and changing the operating principles of their plants by integrating elements of digital platforms and infrastructure. However, the accelerating nature of these changes limits our ability to make reliable forecasts. For example, in 2002, the most optimistic predictions suggested that, starting from 2010, solar energy capacity would grow by $1 \mathrm{GW}$ per year [World Energy Outlook, 2002]. However, in truth, in 2010 the actual capacity was 17 times larger than predicted, and in 201799 times larger [Global Market Outlook..., 2018]. On the other hand, these trends are opening new opportunities for businesses to make a priority of, and give preference in decision making to, environmental protection, the support and development of local communities, the reduction of emissions from production or other principles of sustainable development.

Under the influence of SDGs, many MNCs are actively transforming their business models, rethinking longstanding corporate values, and changing their positioning in the market [Bohnsack, Pinkse, Kolk, 2014]. A notable example is the industry of commercial transport. Previously companies manufacturing transportation vehicles tended to consider themselves predominantly as manufacturers, but today many of these firms strive to position themselves to their clients as providers of transport solutions. Overall, the boundaries of the traditional transport industry have been widened by involving an increasing number of companies from other sectors of the economy. In this paper, I consider the example of the Swedish company Scania, which is currently moving in this direction. Scania is one of the world's largest producers of heavy goods vehicles, buses, industrial and marine engines, and its approach to the integration of the principles of sustainable development into its business processes is worthy of attention and useful to understand.
Scania is distinguished by the following particularities:

- having been founded at the end of the XIX century, it has a long history over which the company has managed to maintain its industrial profile and the strong competitiveness of its industrial products;

- the principle shareholder in the company is the Traton Group, which is part of the German automotive concern Volkswagen and unites several producers of heavy- and medium-tonnage commercial vehicles, including MAN and VW Caminhões e Ônibus;

- it conducts production operations in Sweden, France, Holland, Poland, Brazil, and Argentina, and also has assembly plants in Russia, South Africa, India, Thailand, Malaysia, and Taiwan;

- it conducts research and development that encompasses the whole chain of its activities, from basic research and testing to quality control and the release of innovative solutions into the market. It also applies for more than 300 national patents every year;

- it has sales and service departments in most of countries across the world, which highlights the trans-national character of its business;

- it has a staff of around 52 thousand employees, composed of more than 100 different nationalities that represent different cultures and religious communities.

The company is particularly interesting in the sense that its strategic top management decisions, on the one hand, engage almost every corporate function and business unit in the achievement of the SDGs, and, on the other, focus the management team on generating additional income and increasing profitability.

The goal of this paper is to investigate the connection between various aspects of the sustainable development paradigm and the commercial success of business. Exploring the concrete business practices of Scania, the paper illustrates how companies may adjust their strategic behavior, approaches, and positioning in the global market to be in line 
with SDGs, and still increase their profitability.

The remainder of the paper is structured as follows. In the first section, I consider the range of Scania's business practices, covering logistical operations, service solutions, alternative energy sources and other areas where new projects and initiatives have been launched due company engagement in the goals and principles of sustainable development. The second section is devoted to an analysis of the steps taken by Scania's top management to integrate sustainable development principles into the company's main goals, management structure and corporate culture, longside the creation of a proper reporting system. The section is followed by the analysis of the effects brought about by Scania's sustainable development strategy in connection to the company's key production and financial performance indicators.

\section{PRACTICES OF SUSTAINABLE DEVELOPMENT IN SCANIA}

\section{Logistical operations}

The transnational character of Scania and the worldwide dispersion of its production and storage facilities define the need for an in-house fleet of transport vehicles employed in its own logistics operations. Additionally, the in-house transport fleet is an excellent way to conduct tests and trials under world real conditions, allowing the analysis of fuel consumption and the energy efficiency of the fleet. To that end, in 2008, Scania decided to introduce a subsidiary division, the Scania Transport Laboratory, which functions as a logistics company and fleet manager, containing around 50 tractors and 120 trailers. It is employed in the transportation of various goods (parts, components, etc.) between the company's plants in Södertälje (Sweden) and Zwolle (Netherlands), and also for performing weekly delivery operations to warehouses. The distance between the cities is around
$1300 \mathrm{~km}$, and the route passes through Copenhagen, where drivers are changed during a regular shift. Every year, each longdistance tractor travels on average 400 thousand $\mathrm{km}$, and a distribution truck travels 30 thousand $\mathrm{km}$, while the annual mileage of the company's fleet as a whole reaches around $7 \mathrm{mln} \mathrm{km}$.

Such a significant scope of activity opens opportunities for increasing energy efficiency in the logistics chain. Importantly, in 2010-2014, the Scania Transport Laboratory conducted an experiment in its fleet which showed that it is economically advantageous for logistics companies to spend money even on very expensive vehicles if they have lower in operating costs. Vehicles with higher operational, functional, and ecological parameters, in one way or another, pay off their higher initial investment costs, thanks to their reduce fuel consumption in the transportation of goods. Calculations showed that due to technological innovations in the vehicles, the average fuel consumption of the Laboratory's fleet over the period examined fell from 35 to $23 \mathrm{l}$ per $100 \mathrm{~km}$, and the $\mathrm{CO}_{2}$ emissions per transported tonne reduced from $70 \mathrm{~g}$ to $28 \mathrm{~g}$, which also allowed significant savings on fuel costs and improved the environmental performance of the fleet [Scania Annual and Sustainability Report, 2018].

In this way, investments in energy efficiency and fuel savings in line with SDG No. 7 "Affordable and Clean Energy" also allow the company to increase the profitability of its in-house cargo transport. Analogous results could also be achieved by those independent logistics organizations and carriers who "embed" energy efficiency into their corporate values and principles.

\section{Service solutions}

Apart from the production and shipment of cargo vehicles, Scania made a strategic decision to develop a range of related services for its clients, the majority of which have been developed with digital technologies and in-

PЖM 18 (1): 103-116 (2020) 
novations. A key component of these services is the communicator embedded in vehicles that allows them to "connect" to the Scania Fleet Management System (FMS), a custom development by the company. The communicator collects various information from the on-board systems of the vehicle about the details of its performance, efficiency, and how it is being driven. It also assesses various operational markers such as location, current state of its components and assemblies, fuel consumption, and $\mathrm{CO}_{2}$ emissions. This collection of data is sent in realtime to a special portal for where it is processed, analyzed and reports are prepared. These reports, both for every vehicle and for the fleet as a whole, are released daily, weekly or monthly depending on the needs of the owner company of the fleet. This data allow the owners to maximize productivity and increase the safety of their vehicles, to control and lower operational costs and environmental harm, to optimize routes and transport needs, to identify the inefficient parts of their logistical chain and so on.

Scania provides this data as a part of both paid and free service packages, depending on the specific options and functions chosen. For example, one of the paid packages gives clients direct, round-the-clock access to all their fleet data through the FMS portal and also allows the data received from Scania vehicles to be integrated with the telematic systems of vehicles from other manufacturers, which is an important feature for owners of multi-brand fleets.

Thanks to the fleet management system, other types of "connected" service are also possible. For example, it can be used to assess and improve the skills of the professional drivers, thereby achieving better driving performance. This is because the system is able to determine driving style and select the most appropriate individual training program for each driver, including theoretical and practical issues of effective vehicle operation. The program additionally provides the driver with a direct connection to a certified Scania instructor, who, with the help of the FMS, identifies the mistakes made during operation, and provides advice in an online mode to help correct those mistakes.

Demonstrative in this regard is the project realized in 2018 by the company's Russian division, Scania-Rus. The project's aim was to reduce diesel fuel consumption in a partner transport company's fleet, which was comprised of 33 Scania G400 tractors. The project also included the training of 33 professional drivers, and keeping records of their results both before and after training. As a result of the project, fuel consumption for the whole fleet fell by $3.1 \mathrm{l}$ per $100 \mathrm{~km}$, which, with an average annual mileage of 180 thousand $\mathrm{km}$ per tractor, led to the saving of 5,600 l of fuel per year, the equivalent of around $€ 3,500$ per vehicle or $€ 116$ thousand for all 33 tractors [Scania Introduces..., 2019]. Moreover, the cost of the training program to the transport company was around $€ 700$ per driver, or $€ 23$ thousand for all the drivers involved in the project. Consequently, thanks to the project, Scania-Rus generated additional revenue. The transport company achieved annual savings of $€ 90$ thousand; its vehicle operating costs decreased substantially because of better driving performance and productivity (reduction in wear on brake pads and other parts) ${ }^{1}$; and the tractors' carbon footprint was reduced by $490 \mathrm{t}$ per year.

The enhancement of the service components in transport to enable the achievement of SDG No. 9 "Industry, Innovation and Infrastructure" also allows Scania to increase its competitiveness in the global market alongside its overall profitability, all while developing in accordance with the principles of sustainable development. It is interesting in this regard that, in 2018, the share of revenue from service related products constituted $19 \%$ of the company's income and the number of "connected" Scania vehicles reached 360 thousand worldwide, including

1 All calculations have been converted into euro, based on the Bank of Russia exchange rate of 03.08.2019: 1 euro $=71.71$ rubles . 
26 thousand in Russia [Scania Annual and Sustainability Report, 2018].

\section{Alternative energy sources}

A very notable trend in various industries is the transition to the use of renewable and clean energy sources, in particular, wind and solar energy. In addition to positive environmental effects, such measures have increasingly begun to demonstrate commercial feasibility, as evidenced, for example, by the fact that over the past four decades the cost of solar cells (photovoltaic modules) has fallen by 99\% [Trancik, Cross-Call, 2013, p. 6678] due to constant improvement in technologies and increases in capacity and efficiency.

As part of that paradigm, Scania has initiated a number of projects to expand the use of renewable energy in its production facilities. For example, in 2017, the company implemented a project to outfit its plant in Zwolle (Netherlands) with solar cells on its roof, covering an area of 55 thousand $\mathrm{m}^{2}$, comparable to eight football fields. The entire surface of the roof has 22 thousand solar panels with a total capacity of $6 \mathrm{MW}$, which, combined with two wind generators added in the adjacent territory that have a capacity of $5 \mathrm{MW}$, supplies the plant with all of its electricity needs [Scania Annual and Sustainability Report, 2018].

This all leads to the fact that investments in renewable energy allow not only the supply of production with fossil free energy, contributing to the achievement of SDG No. 7 "Affordable and Clean Energy" and SDG No. 13 "Climate Action", but also the launch of innovative, and, most essentially, paid-off projects.

\section{Recycling of resources and materials}

An important factor in the efficiency of business is the maximum use of resources and materials in the manufacture of products. Many MNCs are transitioning to the use of recycled materials as a possible way to low- er production costs, reduce negative environmental effects and increase efficiency of production methods.

Noteworthy in this respect is Scania's new project for the restoration of outworn components and parts for used trucks and buses. As part of the project, vehicle owners have the opportunity to turn in components that have been removed from service and, through the company's exchange fund, to receive restored parts for a much lower price. The parts all undergo full restoration at the manufacturing plant, have a high quality, are tested and come with the same warranty conditions as new parts. As a result, the life cycles of all categories of devices and parts (motors, generators, gearboxes, clutch assemblies, flywheels, starters, injectors, turbo compressors, etc.) were extended, while the aggregate volume of material to be disposed of and not reused was significantly decreased. Additionally, the restoration of parts requires significantly less energy, materials, and resources than the production of new parts. Through this project, Scania has not only obtained additional income, but also made a contribution to the achievement of SDG No. 12 "Responsible Consumption and Production".

\section{Non-traditional types of fuel}

Requirements regarding vehicle emissions levels are being tightened globally. While at the beginning of the XXI century, emissions norms matching the Euro-3 ecological standard were in force in EU countries, over the past 15 years the requirements have increased to the point that automotive companies are now prohibited to produce vehicles with emissions levels lower than Euro-6, and that is not the end goal. It is possible, of course, to combat this trend, making very risky attempts to circumvent the requirements with the help of new technological devices and sensors, but this exposes one's business reputation and brand image to risks. However, it is also possible to search for the new op-

PЖM 18 (1): 103-116 (2020) 
portunities hidden within this trend, by turning to the development of solutions that run on non-traditional types of fuel. In this regard, Scania has achieved very interesting results. The strategic decision to invest in the development of engines running on alternative fuels has led to company, today, being able to offer trucks that operate on ethanol, hydrotreated vegetable oil, biodiesel, biogas, natural gas and hybrids while hydrogen fuel cells and electric solutions are currently under development. Thousands of such trucks are already operating around the world, making a significant contribution to the reduction of emissions of greenhouse gases, nitrogen oxides, and other harmful substances into the environment, while at the same time improving mobility in cities and providing additional profitability to the company. In Russian conditions, the greatest potential lies in transport running on natural gas (CNG, LNG). The first Scania gas trucks were delivered to clients in Russia in 2015, and since that time the Scania gas vehicle fleet has reached 600 units, providing aggregate natural gas consumption in Russia of $40 \mathrm{mln} \mathrm{m}^{3}$ per year, as well as annual fuel cost savings of $€ 14 \mathrm{mln}$ for cargo carriers [Zubko, 2020].

Thus, the company is both making a significant contribution to the achievement of SDG No. 13 "Climate Action", SDG No. 9 "Industry, Innovation and In-frastructure" and SDG No. 11 "Sustainable Cities and Communities" while opening additional avenues of income for itself. In 2018, Scania sold 4,540 trucks and buses running on nontraditional types of fuel, which made up $4.5 \%$ of the total number of vehicles sold [Scania Annual and Sustainability Report, 2018].

\section{Partnership with suppliers and government}

The increasing involvement of MNCs in the achievement of the SDGs and the launch of new projects that make contributions in that area is creating models of behavior for smaller business and, hence, is "dragging" them into these processes. Some practices are already well-known such as when MNCs integrate requirements, specifications and criteria compatible with the principles of sustainable development into their procurement procedures, and also develop various sustainability questionnaires and tests determining the level of suppliers' commitment to the SDGs. Scania-Rus, for example, when purchasing snow removal services for its service truck and bus workshops chooses only those suppliers who can guarantee the disposal of the snow in snowmelters, which ensures that the snow is not subsequently disposed of in natural areas and so does not pollute the aquatic environment. Such practices affect the company's business reputation in a positive way, helping increase the loyalty of its customers.

At the same time, it should be noted that similar efforts of MNCs in the field of sustainable development would be less effective without regulatory action and partnership with the state, both in terms of the tightening of certain requirements and of the stimulation of business' activities in that sphere. Stimulating activity from the state is necessary, most of all, for the formation of new, breakthrough markets, which are able to make a significant contribution to the achievement of the SDGs, but which are "unaffordable" if taken by business alone. Take the electric vehicles market, for example, the appearance of which was promoted in the EU countries through different types of subsidies and preferences, but in the end appeared in a whole range of countries, thereby allowing a "low-carbon society" to be achieved. It is interesting that in Norway, electric vehicles became cheaper than many traditional automobiles and constituted $46 \%$ of all new cars purchased in 2018 (a growth of $40 \%$ in comparison with the previous year). In terms of the total automobile fleet comprising $2 \mathrm{mln}$ cars, the share of eco-friendly automobiles reached 10\% [Global EV Outlook, 2019]. Many European cities follow similar paths when they opt to ban vehicles using internal combustion engines from their city centers or even from 
their territories altogether. Consequently, if businesses receive early indicators of their city's strategic priorities, they can adjust their business models, production programs, research and developments, according to the emerging needs and the expected demand.

Emphasizing the importance of stimulating measures in the birth of new industries and markets, it is worth paying attention to the factors that have led to the radical reduction in the cost of solar cells in recent decades. Researchers have come to the conclusion that the central role in this process was played by the "market-stimulating policies" taken by the state, which, together with "private R\&D, economies of scale, and learning-by-doing" allowed a reduction in costs of $60 \%$ and made solar energy accessible to a wide range of users around the world [Kavlak, McNerney, Trancik, 2018]. Similar effects, achieved thanks to the joining of the interests of MNCs and the state, testify to both the successes in the achievement of SDG No. 17 "Partnerships for the Goals" and the emerging of new business opportunities enabling to additional income to be generated.

\section{SUSTAINABLE DEVELOPMENT: MANAGEMENT PRACTICES AND REPORTING}

Engaging businesses in the process of achieving sustainable development goals, systemwide and over the long term, primarily requires the integration of sustainable development principles within an organization's main goal, management structure and its corporate culture. Scania took the first steps in this area in 2012, when the company's executive board and President and CEO made a strategic decision to sign the UN Global Compact, a global initiative for corporate social responsibility and sustainable development. The company committed to integrating the UN's ten globally accepted principles related to human rights, labor, environment, and anticorruption into its most important internal corporate documents: Scania Code of conduct,
Scania Group descriptions, policies, standards and regulations.

Given the cross-functional nature of the issues covered by the sustainable development paradigm, a special body was established as part of Scania's management structure, namely the sustainability advisory board. It reports directly to the executive board and is authorized to pursue strategic policy, prepare and implement management solutions throughout the company's business units, ensure the coordination and alignment of the efforts of different management lines, develop KPIs for sustainable development, and monitor the achievement of targets. The sustainability advisory board was composed of representatives of all corporate functions - Research and development, Production and logistics, Sales and marketing, Commercial operations, Financial services, Purchasing and Human Recourses, under the leadership of Scania's senior Vice President responsible for communication, brand, marketing, and sustainable development. In addition, the Sustainable Transport Development Department was established as a part of the company headquarter. It was intended as a back office for the advisory board, responsible for operational activities and setting-up the relevant business processes. In addition, Sustainability Manager positions were established in Scania's subdivisions that operate in strategic markets. These managers are responsible for work at a local level and report to the Head of the Sustainable Transport Development Department at the company's headquarters. In Scania-Rus, the sustainable development roles were combined with the existing government relations functions, and the newly-formed position was assigned the status of department director.

The transformation initiated by the sustainability advisory board affected Scania's main goal, first and foremost. In particular, its focus areas were adjusted: the focus on providing the best profitability for its customers by delivering optimized heavy trucks and buses, engines and services was replaced by a shift towards a sustainable transport system, creating a mobile world that is better

PЖM 18 (1): 103-116 (2020) 
for business, society and the environment. The relevant transformation also impacted the company's values and principles, as well as its key governing documents and business processes, which had core aspects of sustainable development incorporated into them in a phased manner (e.g. binding provisions that stipulated the installation of environmentally-friendly stations for the safe storage and disposal of waste and chemicals were included in the operational standards for Scania's dealers worldwide).

After a short time, Scania started disclosing information to its stakeholders that contained a detailed description of the company's progress in the implementation of SDGs during the calendar year (the relevant information is published on the official website of the UN Global Compact in the form of a Communication on Progress). Also, since 2015, Scania has been publishing its annual report and sustainability report as a single comprehensive document drawn up in accordance with the principles and requirements of international reporting standards. Following the approval of the 17 Sustainable Development Goals by the UN General Assembly, the company started reporting its progress in achieving each of the goals.

In addition to the effort by the top management, various stakeholders are increasingly contributing to the engagement of their business in the implementation of SDGs. As a general practice, the materiality assessment is conducted annually at Scania in accordance to the guidelines of the Global Reporting Initiative (GRI). Besides identifying areas and aspects of the transport industry and Scania's business that appear to be most significant and relevant for stakeholders, the assessment aims to identify the optimal balance between the company's short-term financial goals and its long-term social and environmental commitments. On the basis of the assessment that was conducted in 2014, 35 topics were identified that may impact Scania's business in the long run. The selected managers of the aforementioned corporate functions analyzed these topics in view of their importance for four groups of stakeholders, namely active employees, financial organizations, society (regulatory bodies, non-government organizations, and the media), and private companies (customers and suppliers). They conducted a series of studies, detailed surveys, and interviews with representatives of each of the groups. Analysis of the data provided an insight into the areas of Scania's business that are especially significant for stakeholders and are in line with the sustainable development paradigm. In particular, the 14 significant areas specified below were identified, which were later approved by the sustainability advisory board and formed the basis for [Scania Sustainability Report, 2014]:

1) sustainable logistics systems;

2) sustainable mobility systems;

3) road safety and security;

4) human rights;

5) emerging markets strategy;

6) safety, health and work environment;

7) community impacts and contributions;

8) intelligent transport technologies;

9) low-emissions technologies;

10) lifecycle optimization;

11) operational efficiency;

12) long-term financial viability;

13) attraction and retention of competence;

14) integrity and compliance.

In the following years, the list of significant areas was extended. For example, in the course of the 2017 assessment, on the basis of three overarching categories of sustainable transport, responsible business and long-term business value, stakeholders highlighted the following areas as being top priority (Table 1) [Mapping What Matters, 2017].

On the basis of these significant areas, specific KPIs were introduced that allow Scania to calculate the contribution of a project, initiative, or activity related to sustainable development to the company's financial and economic performance. These indicators are applied at the headquarter level and at that of the company's divisions all around the world, and are also fixed to business planning over the long term. Among the indica- 
Most significant sustainability areas identified by Scania in 2017

\begin{tabular}{|c|c|c|}
\hline Sustainable transport & Responsible business & Long-term business value \\
\hline $\begin{array}{l}\text { - Smart transport / } \\
\text { - } \mathrm{CO}_{2} \text { reduction } \\
\text { - Energy efficiency } \\
\text { - Electrification } \\
\text { - Alternative fuels } \\
\text { - Safe transport } \\
\text { - Emission reduction (SOx, } \\
\text { NOx, particles, noise) }\end{array}$ & $\begin{array}{l}\text { - Safe, healthy and productive } \\
\text { work environment } \\
\text { - Human and labor rights } \\
\text { - } \text { Diversity and inclusion } \\
\text { - } \text { opesource and energy efficient } \\
\text { - Integrity and anti-corruption } \\
\text { - Circular economy } \\
\text { - Community impact }\end{array}$ & $\begin{array}{l}\text { - Customer satisfaction } \\
\text { - } \text { - Lusiness development } \\
\text { - Industry and academy } \\
\text { partnership } \\
\text { - Innovations } \\
\text { - Corporate strategy } \\
\text { - Attraction and retention of } \\
\text { employees } \\
\text { - Viability of long term customer } \\
\text { and supplier contacts }\end{array}$ \\
\hline
\end{tabular}

Key multi-year financial ratios and other figures of Scania Group

\begin{tabular}{|c|c|c|c|c|c|c|c|}
\hline Indicator & 2018 & 2017 & 2016 & 2015 & 2014 & 2013 & 2012 \\
\hline \multicolumn{8}{|c|}{ Number of vehicles produced, units: } \\
\hline Trucks & 92679 & 87454 & 75452 & 72382 & 75287 & 75957 & 60647 \\
\hline Buses & 8696 & 8327 & 8488 & 6964 & 6921 & 6897 & 6283 \\
\hline Total & 101375 & 95781 & 83940 & 79346 & 82208 & 82854 & 66930 \\
\hline Net sales, mln euro & 13365 & 12797 & 10974 & 10160 & 10116 & 10040 & 9150 \\
\hline Operating income, mln euro & 1348 & 1290 & 668 & 1032 & 958 & 977 & 954 \\
\hline Net income, mln euro & 914 & 903 & 342 & 723 & 660 & 716 & 763 \\
\hline Return on assets (ROA), \% & 4.66 & 4.93 & 1.99 & 4.78 & 4.52 & 5.25 & 5.87 \\
\hline Return on equity (ROE), \% & 17.24 & 17.44 & 7.66 & 17.85 & 14.38 & 16.69 & 18.97 \\
\hline $\begin{array}{l}\text { Number of employees } \\
\text { (as of December 31st) }\end{array}$ & 52103 & 49263 & 46243 & 44409 & 42129 & 40953 & 38597 \\
\hline
\end{tabular}

N o t e: in Scania's annual reports for a particular year, financial performance indicators are expressed in SEK, while for this paper they have been converted into euro, based on the average annual exchange rate of the European Central Bank.

B a s ed o n: [Scania Annual and Sustainability Report, 2012-2017; 2018].

tors, it is possible to differentiate between those which have a direct relationship with financial income (number of drivers trained, service contracts concluded, vehicles for alternative fuels sold, etc.) and those which demonstrate responsibility when conducting business (number of occupational accidents with sick leave; diversity and inclusion index; $\mathrm{CO}_{2}$ emissions from land transport; volume of non-recycled waste; and a number of oth- ers). All KPIs are included in Scania's annual and sustainability report for the corresponding year.

It should be noted that the adopted management solutions for integrating the sustainable development principles in Scania's business, as well as further changes to its corporate culture, had a positive effect on the company's production and financial performance and its market position world- 
Table 3

Key multi-year financial ratios and other figures of Scania-Rus

\begin{tabular}{l|l|l|l|l}
\hline \multicolumn{1}{c|}{ Indicator } & $\mathbf{2 0 1 8}$ & $\mathbf{2 0 1 7}$ & $\mathbf{2 0 1 6}$ & $\mathbf{2 0 1 5}$ \\
\hline $\begin{array}{l}\text { Number of truck } \\
\text { sales in Russia, } \\
\text { units: }\end{array}$ & 6679 & 5702 & 2518 & 2547 \\
\hline $\begin{array}{l}\text { Net sales, } \\
\text { mln euro }\end{array}$ & 707 & 607 & 281 & 229 \\
\hline $\begin{array}{l}\text { Net income, } \\
\text { mln euro }\end{array}$ & 27 & 20 & 9 & 8 \\
\hline $\begin{array}{l}\text { Return } \\
\text { on assets } \\
\text { (ROA), } \%\end{array}$ & 14.94 & 13.75 & 9.60 & 10.06 \\
\hline $\begin{array}{l}\text { Return on aquity } \\
\text { (ROE), } \%\end{array}$ & 31.05 & 30.10 & 21.52 & 18.54 \\
\hline
\end{tabular}

N ot e: in Scania-Rus balance sheets and income statements for a particular year, financial performance indicators are expressed in rubles, while for this paper they have been converted into euro, based on the average annual exchange rate of the Bank of Russia.

S o u r c e: [Scania-Rus balance sheets...].

wide, as evidenced by the annual and financial reports (Tables 2,3 ).

It is remarkable that in addition to the clearly visible growth in Scania's net sales and profitability since the company got actively engaged in the achievement of the SDGs, a growth in the number of the company's employees it is also noticeable: over the 2012 2018 period this figure increased by $35 \%$. Such findings, in turn, set new challenges related to the analysis of correlating business activities driven by sustainable development and the number of jobs that arise it is also noticeable in certain sectors of the economy. Direct connection between these categories is indicated, for example, by the observed increase in the number of jobs in the field of renewable energy in various countries. Particularly, in the US more than 110 thousand net new clean energy jobs were created in 2018 (an increase of $3.6 \%$ compared to the previous year), bringing the total number of Americans who work in clean energy to 3.26 mln [Clean Jobs America, 2019].
This suggests that the sustainable development agenda is becoming increasingly attractive both to Scania's top management and its stakeholders, and this trend seems to be expanding to more and more MNCs.

\section{CONCLUSION}

This article covers Scania's various projects and business practices launched as a result of integrating sustainable development principles into its business units' operational processes. It also introduces strategic solutions developed by the company's top management. These practices are aimed at achieving sustainable development goals while retaining focus on generating additional revenue for the company.

Despite the fact that businesses generally regard the sustainable development paradigm as a source of financial losses, an increasing range of MNCs' practices are proving them wrong, showcasing a positive correlation between the adoption of sustainable development principles and commercial success.

To engage their corporations in the process of achieving SDGs, top managers ought to strive to reshape and readjust their corporate mission, values and business strategies. They also have to choose the areas and principles of sustainable development that could give rise to projects and initiatives that have economic, environmental, and social benefit, and at the same time increase profitability. Bearing in mind Scania's business profile and specialization, the company's top management decided to focus on breakthrough sustainable development areas, such as energy efficiency, electrification, alternative fuels, smart and safe transport, and also provided its management team with comprehensive support in launching new projects in those respective areas. By implementing a goal-setting system and well-developed indicators for achieving SDGs, the company was able to start conducting work in the aforementioned areas on a systematic basis, making them part of its longterm development strategy. Scania's business practices covered in this article showcase the 
company's significant contribution to achieving the SDGs adopted at the corporate level and confirm the possibility of generating additional revenue by implementing new initiatives, introducing cost-saving measures, and also increasing reputational capital.

It should be noted that these practices cover only part of the company's strategy for sustainable development, and has integrated others which no less important components of that paradigm (quality education, gender equality, good health and well-being, decent work, and others). These are not strictly associated with direct commercial effects, but more with the demonstration of responsibility in the conduct of business and concern

\section{REFERENCES}

2030 Purpose: Good Business and a Better Future. Connecting Sustainable Development with Enduring Commercial Success. 2017. Deloitte. [Electronic resource]. https:// www2.deloitte.com/content/dam/Deloitte/ $\mathrm{ru} /$ Documents/risk/sustainable-development-goals-2030-en.pdf (accessed: 01.07.2019).

Blagov Yu. E., Kabalina V. I., Petrova-Savchenko A. A., Sobolev I. S. 2015. Creating value for business and society: Corporate social performance of Russian companies. Russian Management Journal 13 (2): 67-98. (In Russian)

Bobylev S. N. 2017. Sustainable development for future generations: Economic priorities. The World of New Economy 3: 90-96 (In Russian)

Bohnsack R., Pinkse J., Kolk A. 2014. Business models for sustainable technologies: Exploring business model evolution in the case of electric vehicles. Research Policy 43 (2): 284-300.

Carroll A. B., Shabana K. M. 2010. The business case for corporate responsibility: A review of concepts, research and practice. International Journal of Management Reviews 12 (1): 85-105. for human capital. Nonetheless, they serve as good illustrations of the fact that the sphere of sustainable development has significant potential for evolving from a rather general set of good intentions and socially responsible activities into a line of business with quite specific and tangible commercial effects.

\section{ACKNOWLEDGMENTS}

The author is sincerely grateful to the anonymous reviewers and members of the editorial board for useful comments and suggestions, but he alone is responsible for interpreting the data and conclusions.
Clean Jobs America. 2019. E2. [Electronic resource]. https://www.e2.org/wp-content/ uploads/2019/04/E2-2019-Clean-Jobs-America.pdf (accessed: 28.03.2020).

Dolgikh E., Erlich V. 2018. Sustainable Development. Role of Russia. UN Global Compact Russia. [Electronic resource]. http://www. globalcompact.ru/upload/iblock/376/Itogioprosa_broshyura.pdf (accessed: 01.07.2019). (In Russian)

Eccles R., Ioannou I., Serafeim G. 2014. The impact of corporate sustainability on organizational processes and performance. Management Science 60 (11): 2835-2857.

Global EV Outlook. 2019. IEA. [Electronic resource]. https://webstore.iea.org/globalev-outlook-2019 (accessed: 19.07.2019).

Global Market Outlook for Solar Power 20182022. 2018. SolarPower Europe. [Electronic resource]. https://www.solarpowereurope. org/wp-content/uploads/2018/09/GlobalMarket-Outlook-2018-2022.pdf (accessed: 02.07.2019).

Kavlak G., McNerney J., Trancik J. E. 2018. Evaluating the causes of cost reduction in photovoltaic modules. Energy Policy 123: 700-710. 
Kolk A. 2016. The social responsibility of international business: From ethics and the environment to CSR and sustainable development. Journal of World Business 51 (1): 23-34.

Laudal T. 2011. Drivers and barriers of CSR and the size and internationalization of firms. Social Responsibility Journal 7 (2): 234-256.

Mapping What Matters. 2017. [Electronic resource]. https://www.scania.com/group/en/ mapping-what-matters/ (accessed: 13.03.2020).

Porter M. E., Kramer M. R. 2019. Creating shared value. In: Lenssen G., Smith N. (eds). Managing Sustainable Business; 323-346. Springer: Dordrecht.

Scania Annual and Sustainability Report. 2012-2017. [Electronic resource]. https:// www.scania.com/group/en/section/sustainability/sustainability-reports / (accessed: 06.07.2019).

Scania Annual and Sustainability Report. 2018. [Electronic resource]. https://www. scania.com/group/en/wp-content/uploads/ sites/2/2019/03/scania-annual-and-sustainability-report-2018-1.pdf (accessed: 06.07.2019).

Scania-Rus Balance Sheets and Income Statements 2015-2018. [Electronic resource]. https://www.audit-it.ru/buh_otchet/ 5032073106_ooo-skaniya-rus (accessed: 06.07.2019). (In Russian)

Scania Introduces New Digital Solutions for Freight Carriers. 2019. Scania. [Electronic resource]. https://www.scania.com/ru/ru/home/experience-scania/news-and-events/News/Scania_na_ XIII_mezhdumarodnom_navigacionnom_forume.html (accessed: 08.07.2019). (In Russian)

Scania Sustainability Report. 2014. Scania. [Electronic resource]. https://www.scania. com/group/en/wp-content/uploads/sites/ 2/2015/12/Scania_Sustainability_Report 2014_tcm40-465595.pdf (accessed: 13.03.2020).

Scott L., McGill A. 2018. SDG Reporting Challenge. PwC. [Electronic resource]. https:// www.pwc.com/gx/en/sustainability/SDG/ sdg-reporting-2018.pdf (accessed: 01.07.2019).

Trancik J. E., Cross-Call D. 2013. Energy technologies evaluated against climate targets using a cost and carbon trade-off curve. Environmental Science \& Technology 47 (12): 6673-6680.

World Energy Outlook. 2002. IEA / OECD. [Electronic resource]. https://www.oecdilibrary.org/docserver/weo-2002-sum-en. pdf? expires $=1563376858 \& i d=i d \& a c c n a m e=$ guest\&checksum $=6 \mathrm{~F} 06 \mathrm{~F} 138 \mathrm{FF} 8472 \mathrm{C} 52 \mathrm{CC} 9 \mathrm{~B}$ D5450A7E0D0 (accessed: 02.07.2019).

World Population Prospects. 2019. UN. [Electronic resource]. https://population.un.org/ wpp/ (accessed: 01.07.2019).

Zubko R. 2020. About 600 Scania gas trucks operate in Russia. Dvizhok. [Electronic resource]. https://dvizhok.su/komtrans/ v-rossii-rabotayut-okolo-600-gazovyix-gruzovikov-scania (accessed: 27.02.2020). (In Russian)

Initial Submission: August 13, 2019

Final Version Accepted: March 26, 2020

\section{Доходность ТНК в контексте устойчивого развития: бизнес-практики Scania}

\section{В. Р. Паривания}

Институт социальных наук, Российская академия народного хозяйства и государственной службы при Президенте РФ (РАНХиГС), Россия; «Скания-Русь», Россия

В статье исследуется связь отдельных аспектов парадигмы устойчивого развития с коммерческим успехом бизнеса на примере транснациональной корпорации Scania. Несмотря на широкую дискуссию о необходимости активного вовлечения бизнеса в реализацию целей устойчивого развития на глобальном и национальном уровнях, конкретные действия для этого предпринимает лишь небольшое число таких корпораций. В действительности приверженность 
корпораций данным целям часто носит декларативный характер, а организационные действия, подчеркивающие социальную ответственность и природоохранные обязательства, лишь в редких случаях увязываются с извлечением дохода. В работе предпринята попытка рассмотреть устойчивое развитие как источник новых бизнес-возможностей, приносящих корпорациям дополнительный доход. C опорой на конкретные бизнес-практики компании Scania в статье иллюстрируется пример того, как корпорации могут корректировать свои стратегии поведения, подходы и позиционирование на глобальном рынке в контексте парадигмы устойчивого развития. Анализ базируется на использовании публичной отчетности и официальных документов Scania, а также сайта компании и открытых источников.

Ключевые слова: устойчивое развитие, транснациональные корпорации, Scania, бизнеспрактики, цифровые технологии, корпоративная социальная ответственность.

JEL: F64, M14, Q01, Q42, Q56.

For citation: Partsvaniya V. R. 2020. Profitability of multi-national corporations in the context of sustainable development: Scania business practices. Russian Management Journal 18 (1): 103-116.

Статья поступила в редакиию 13 августа 2019 г.

Принята к публикаиии 26 мларта 2020 2. 